\title{
Employment Impacts of Cleaner Production -
}

\section{Evidence from a German Study Using Case Studies and Surveys}

\author{
Friedhelm Pfeiffer, Klaus Rennings* \\ Zentrum für Europäische Wirtschaftsforschung (ZEW), \\ Centre for European Economic Research, \\ Mannheim, \\ Germany \\ *Corresponding Author: \\ P.O. Box 103443, D-68161 Mannheim, \\ Phone: ++49/621/1235-207, Fax: ++49/621/1235-226, \\ e-mail: rennings@zew.de
}




\section{Non-technical summary}

The study assesses net employment effects of technical progress which can be expected by the ongoing transition from end-of-pipe technologies towards cleaner production. Empirical evidence is presented on the basis of case studies and panel data including a telephone survey in German industry. The main result ist that cleaner production leads in more firms to a net creation of jobs than end-of-pipe technologies. However, eco-innovations like other innovations tend to require higher qualification. Thus, the demand for skilled and high-skilled labour rises while the demand for unskilled labour decreases. The results imply that supporting cleaner production is not in conflict with labour market policy. Synergies are identified, they are however small and specific. Thus, technology policy in general and supporting cleaner production in particular can not be expected to give substantial contributions to the solution of mass unemployment in Germany without using additional instruments (e.g. concerning a reduction of labour costs, increasing flexibility of labour markets).

submitted to: Business Strategy and the Environment, May 1999

paper category: BSE Policy and Practice Reviews 


\section{Introduction}

In Germany, the protection of the environment has increasingly developed to an important economic sector with nearly one million employees (Blazejczak et al., 1994; DIW et al., 1996). In the face of the continuing high level of unemployment, the question arises whether further efforts for cleaner production may lead to a change in unemployment and if so, under which conditions. Politicians and other relevant societal groups increasingly search for strategies which help to further enhance the quality of the environment and at the same time increase employment (Bovenberg/van der Ploeg, 1994; Goodstein, 1995; Schneider, 1996). Up to now, our understanding about the relationship between environmental protection, specific environmental technologies and employment is comparably little deve loped.

Often an accelerated transition from end-of-pipe to integrated environmental technology is demanded, hoping that this will simultaneously stimulate both the environment and competitiveness (Porter/van der Linde, 1995). Up to now, employment effects of integrated environmental technologies could not be quantified. Positive as well as negative effects are possible (cf. Table 1). Many fear that an environmental policy focusing on integrated technologies will result in job losses in the end-of-pipe sector; moreover, reduced energy and material consumption may also lead to losses in both production and jobs. However, such considerations are contradicted by forecasts that additive technologies will continue to have considerable market opportunities, since ecological optimisation often requires the simultaneous use of integrated and additive technologies (Coenen/Klein-Vielhauer/Mayer, 1995). It is argued that the employment effects of environmental technologies are determined by their impacts on innovation as well as on international competitiveness (Blazejczak/Edler/Gornig, 1993). In this respect, integrated technologies seem to have advantages because of their competitive edge and comparably low costs for users. 
Table 1: $\quad$ Possible Impacts of Green Production on Employment

\begin{tabular}{|l|l|}
\hline \multicolumn{1}{|c|}{ Potential negative effects } & \multicolumn{1}{c|}{ Potential positive effects } \\
\hline $\begin{array}{l}\text { Job losses in enterprises using end-of-pipe } \\
\text { (additive) environmental protection tech- } \\
\text { nologies }\end{array}$ & $\begin{array}{l}\text { New jobs for brokering, consulting and fi- } \\
\text { nancing agencies for integrated environmental } \\
\text { protection (cleaner production) (e.g. energy } \\
\text { agencies) }\end{array}$ \\
\hline $\begin{array}{l}\text { Job losses in the vendors of additive envi- } \\
\text { ronmental protection technologies }\end{array}$ & $\begin{array}{l}\text { New jobs for developers and suppliers of green } \\
\text { production as well as energy and resource sav- } \\
\text { ing technologies }\end{array}$ \\
\hline $\begin{array}{l}\text { Job losses in the energy sector (produc- } \\
\text { tion and conversion) and in resource ex- } \\
\text { traction and processing due to a decrease in } \\
\text { production effected by an improved energy } \\
\text { and material efficiency/lower material in- } \\
\text { puts in production processes }\end{array}$ & $\begin{array}{l}\text { New jobs by "win-win options" brought about } \\
\text { by uned resources elsewhere }\end{array}$ \\
\hline $\begin{array}{l}\text { Job losses in the investment goods industry } \\
\text { supplying the energy and resource extract- } \\
\text { ing sector }\end{array}$ & $\begin{array}{l}\text { New jobs due to increased competitiveness by } \\
\text { using production and product integrated tech- } \\
\text { nologies of environmental protection (cleaner } \\
\text { production) }\end{array}$ \\
\hline $\begin{array}{l}\text { Job losses due to the potential increase in } \\
\text { work productivity linked to the implemen- } \\
\text { tation of green production technologies }\end{array}$ & $\begin{array}{l}\text { Fewer crowding out effects and higher profit- } \\
\text { ability of investment in clean technologies than } \\
\text { for the use of additive technologies }\end{array}$ \\
\hline
\end{tabular}

The aim of this study is to improve the theoretical understanding and empirical evidence of the relationship between integrated technologies and employment. Firstly, terminology as well as the fundamental theoretical approach will be explained (Section 2). The empirical analysis is based upon case studies (Section 3) and on a survey of firms from the manufacturing industry, which was carried out in addition to the 1996 Mannheim Innovation Panel (Section 4). Finally, the findings are summarised in a conclusion (Section 5).

Both case studies and a survey have been chosen in order to live up to the complexity of the topic, which could not have been grasped with one single method. On the following pages, our main task is to derive differentiating and qualitative statements on the interrelationship between integrated environmental technologies and employment. Absolute figures (i.e. statements like "integrated environmental protection technologies create $\mathrm{X}$ hundred thousand 
jobs") were consciously avoided. Even where model calculations led to quantitative results, these are, above all, meant to highlight trends and their relevance.

\section{Basic definitions and concepts}

\subsection{Differentiation between additive and integrated environmental technology}

Environmental technological measures can be differentiated by those belonging to curative (e.g. soil decontamination) or preventive environmental protection. As Figure 1 illustrates, preventive measures can be further subdivided into measures of integrated and additive protection measures. The latter ones are also frequently referred to as end-of-pipe technology.

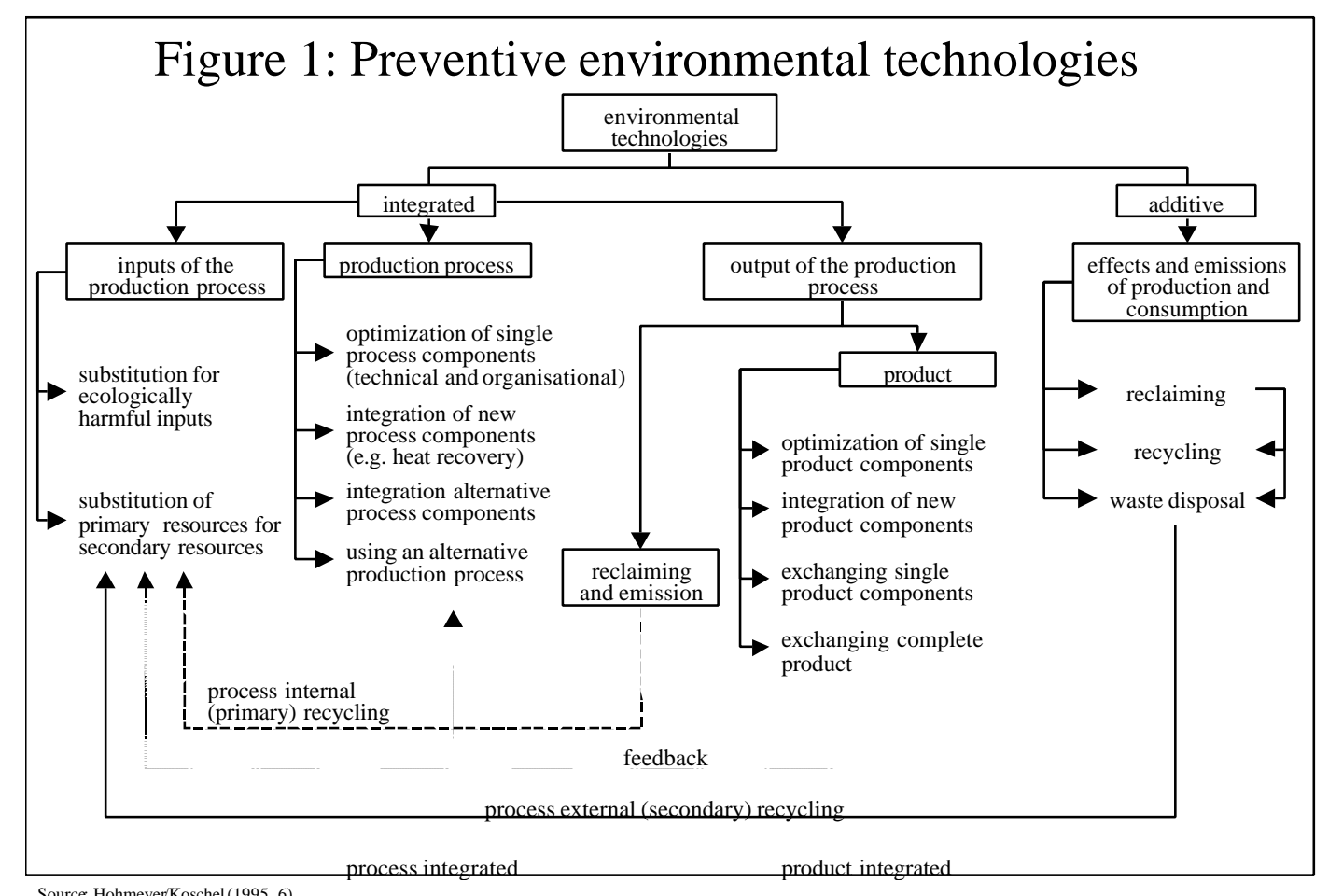

Integrated environmental technology can be subdivided into primary measures (integrated technology in the narrow sense) and secondary measures; the latter ones include processintegrated and process-external recycling technologies (Hemmelskamp, 1997). The Cleaner Production Support Programme (German acronym: PIUS) of the German Ministry of Education, Science, Research and Technology (BMBF) also categorises process-external recycling as integrated environmental protection technology (BMBF, 1994; Hansen, 1996). However, in 
empirical analyses, such a broad definition of integrated environmental technology causes problems to distinguish between additive and integrated measures. Since any residues from end-of-the-pipe processes may find their way back into the production process through certain recycling technologies, every filter technology could be counted among the integrated environmental protection technologies. Thus every additive technology can potentially be integrated, i.e. embedded into a closed loop where residues are led back into the production cycle. In the surveys and case studies we solve the described problem of differentiation by clearly separating primary measures, as well as primary and secondary recycling. Where this is not possible, secondary recycling is attributed to additive environmental technology.

\subsection{Technological progress and labour demand}

From the point of view of companies, the demand for labour results from the turnover and profit expectations, from the relative factor costs, technology and its changes (König, 1997; Stoneman, 1983; Tirole; 1989). Employment effects at the corporate level resulting from changes in technology, e.g. the transition from additive to integrated environmental technologies, depend particularly from the following factors (Blechinger et al., 1998; Katsoulacos, 1986; cf. also Figure 2):

- the current level of technology, which can be described by the substitution elasticities between various factors, the minimal cost company size, and the degree of economies of scope in the case of multi-product firms;

- the type of innovation (product or process innovation), its direction (capital or labour saving, qualification-increasing or qualification-neutral) and intensity (radical vs. incremental change);

- the sector-related and aggregate economic demand (also from abroad), which is characterised by price and income elasticity of demand as well as the degree of complementarity between existing and new or improved goods;

- the competition intensity of goods markets;

- the structure and competition intensity of the factor markets, particularly that of the labour market;

- the skill structure of the work force and their regional and vocational mobility. 
Figure 2: Innovations and their effects on employment conditions

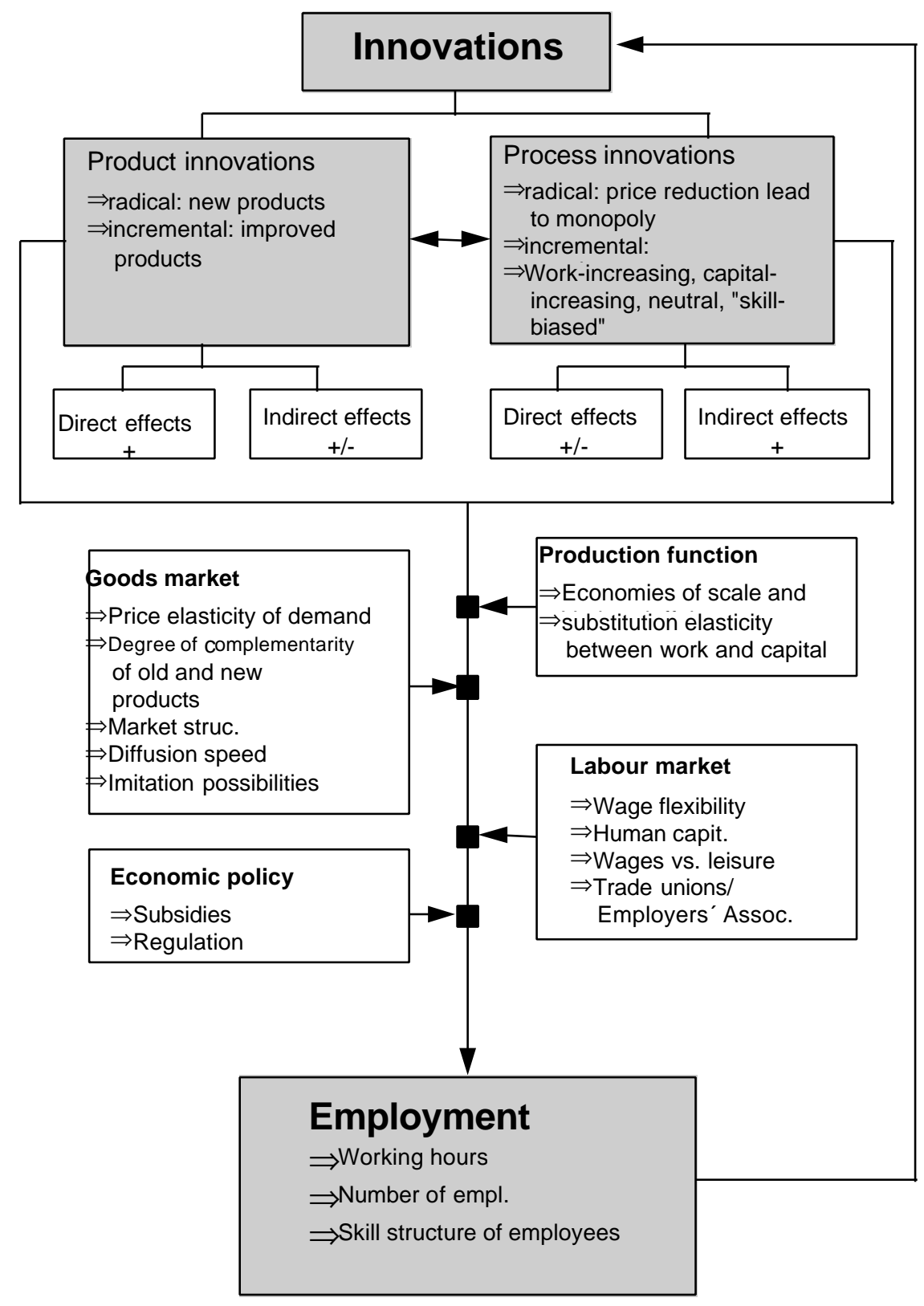

Source: Blechinger/Pfeiffer (1997)

The technological progress has both direct and indirect effects, which release labour or compensate it. If labour productivity is considerably increased, as it is common for process innovations, less work is put into the same output amont. This is referred to as direct effect or as a substitution effect of technical progress which has a cost-reducing effect. Altogether technological progress lowers production costs and makes price reductions or profit increases possible. This in turn increases real incomes and thus demand. This indirect effect can com- 
pensate the labour demand which was diminished by cost reductions. The extent of this compensation is determined by the amount of the price reduction and the price responsiveness of demand.

In contrast to process innovations, this direct effect of product innovations has a positive effect as soon as the new or improved product has been accepted by the market and is creating additional demand for the innovating venture. Indirect effects at corporate level occur with multi-product firms. The product innovation has a positive employment effect if the new goods do not substitute the old products of a company. Positive effects also arise if product innovations create a demand which is complementary to goods of the company which are already on the market. One example for a complementary demand is the hard- and software of computers.

However, positive employment effects become unlikely if old products are to be substituted in the market, the incomes are restricted or if there are synergy effects in production. In the latter case, the joint production of several goods can save input factors and thus costs.

Analogous to quantitative employment effects, the effects of technological progress on demand for different levels of skilled labour can be determined (Hamermesh, 1993). For this purpose, the production factor labour is divided into the two categories of less skilled and highly skilled labour. In this case, the effects of technological change on demand for different degrees of qualification depend on the degree of complementarity of highly and lowly qualified labour, on the complementarity of capital and the various types of work, and on the kind of technological progress.

If process innovations increase the work productivity of high skilled workers, their relative demand (relative to the less skilled) raises, given constant relative wages and disregarding output effects for the moment. While theoretically also the reverse case is possible, literature focuses on the case of skill-increasing technological progress. Although rationalisation measures reduce labour requirements in production, the invention and realisation of new technologies require more highly skilled labour. The growing speed of diffusion and economic change are another reason for the increased demand for skilled labour which can be used flexibly and who are able to design the change (Bartel/Lichtenberg, 1987). Assuming that highly skilled labour with a better general school education face a lower depreciation rate of their knowledge in the course of technological change and are able to respond more quickly to technological changes, technological change increases the demand for qualified labour. 
Summarising it can be stated that from a theoretical point of view, product and process innovations at the individual corporate level can trigger negative or positive employment impulses. This is determined by the size of substitutional and compensational effects. The analysis of employment effects is further increased in complexity if one leaves the corporate level in order to examine the effects of innovations at the level of industries and of the entire economy and has to take into account influential factors like economic policy, labour market, market structure or diffusion speed.

\subsection{Integrated technologies and labour demand}

In the above model of technological change the factor environment was omitted. In a transition from an additive to an integrated environmental technology, it becomes even less possible to clearly determine the direction of the employment effects of environmental product and process innovations. The employment effects are still quite comparable to the general effects of technological change, if the specific integrated environmental technology focuses on minimising costs (e.g. process integrated environmental protection by saving energy) or on increasing turnover (e.g. producers of low-solvent lacquers). However, a different case is it if environmental-politically motivated higher ecological standards have to be complied with (e.g. resulting from requirements to separate, collect or reuse materials and substances).

In some cases integrated process technologies may both save costs and increase employment. In other words, environmental protection can sometimes be a side product of rationalisation investment that is profitable anyway, e.g. with measures of efficient energy use or in the context of a Total Quality Management which is implemented anyway; due to necessary changes in process engineering it can however sometimes also bring about considerable access, information, adjustment and readjustment costs.

If the new environmental technology evokes net costs, employment effects depend last but not least on the environmental-political framework (national early mover role versus coordinated proceeding). In order to identify such influences, the case studies presented in the following section will therefore cover a broad range of integrated environmental protection technologies. 


\section{Case studies}

\subsection{Hypotheses}

For a preliminary systematisation of potential positive and negative employment effects of different kinds of integrated environmental protection, it is possible to formulate ad hoc hypotheses on the interrelation between integrated environmental technologies and employment which build upon the theoretical basis of the preceding section (see Table 2).

Table 2: $\quad$ Direct and indirect employment effects of integrated environmental technolgy

\begin{tabular}{|l|l|l|}
\hline $\begin{array}{l}\text { Types of } \\
\text { integrated } \\
\text { measures }\end{array}$ & Direct employment effects & Indirect employment effects \\
\hline $\begin{array}{l}\text { Primary } \\
\text { measures } \\
\text { (integrated } \\
\begin{array}{l}\text { environmental } \\
\text { technology in a } \\
\text { narrower sense) }\end{array}\end{array}$ & $\begin{array}{l}\text { a) process innovation: } \\
\text { Tendency negative, substitution } \\
\text { b) product innovation: } \\
\text { Tendency positive }\end{array}$ & $\begin{array}{l}\text { a) process innovation: } \\
\text { Tendency positive with process } \\
\text { innovations (compensatory effect) } \\
\text { b) product innovation: } \\
\text { unknown, dependent i.a. on the } \\
\text { degree of complementarity of old } \\
\text { and new products }\end{array}$ \\
\hline $\begin{array}{l}\text { Secondary } \\
\text { measures } \\
\text { (primary and } \\
\text { secondary } \\
\text { recycling) }\end{array}$ & $\begin{array}{l}\text { Tendency positive, additional } \\
\text { employment by closing material } \\
\text { loops }\end{array}$ & $\begin{array}{l}\text { Tendency negative in case of a } \\
\text { nationally restricted action if } \\
\text { production increases in cost } \\
\text { Tendency positive, if integrated } \\
\text { technology can be established in } \\
\text { international markets }\end{array}$ \\
\hline $\begin{array}{l}\text { Organisationa } \\
\text { l measures } \\
\text { (e.g. eco- } \\
\text { audits) }\end{array}$ & $\begin{array}{l}\text { Tendency positive because of } \\
\text { additional value-creation processes }\end{array}$ & $\begin{array}{l}\text { Tendency negative in case of a } \\
\text { nationally restricted action due to } \\
\text { increases in cost } \\
\text { Tendency positive, if integrated } \\
\text { measures can be established in } \\
\text { international markets }\end{array}$ \\
\hline
\end{tabular}




\section{Primary measures}

According to the hypothesis, primary measures of environmental technology as for example emission-reduced processes are in terms of their employment effects comparable to the costsaving technological progress by process innovations, as stages of value-creation are frequently abolished. Moreover, in addition to the ecological effects a rationalisation of the production process is attempted which sometimes also represents the proper motif for the innovation (e.g. Total Quality Management). The hiring e.g. of employees of waste dumps, energy suppliers or in the field of end-of-the-pipe technologies is likely to be reduced by primary measures; also transports can be reduced in certain areas by optimal material flow management. Due to an improvement in the competive position, the indirect effects tend to be positive.

On the other hand, product innovations in integrated environmental protection lead to positive direct employment effects, which can however be partly or entirely offset by their crowding out of previous products. An example is the introduction of low-noise lawn-mowers, which led to more employment in the production of these devices, which are however at least partly compensated by respective losses in the sale of noisy lawn-mowers.

\section{Secondary measures}

In contrast to this, secondary measures of environmental protection (recycling inside and outside of the company) tend to lead to positive direct employment effects as they are accompanied by additional stages of value-creation, above all processes such as cleaning, material separation, reclaiming, maintenance, repairs, and reverse logistics. The indirect employment effects tend to have the opposite effect. While labour-saving technological progress rather causes positive indirect employment effects - for example, the aforementioned labour-saving primary measures - further process stages introduced in the production of a good tends to effect an increase in the price of the product, which would mean a negative impact on competitiveness. However, if in international markets there is a homogeneous regulative trend towards integrated environmental technologies, this can create an additional demand in the market for environmental technology and thus lead to more employment. Therefore the indirect employment effects of integrated environmental technology depend on whether a (regulative) 
trend towards a more integrated environmental technology is restricted to a national level, or can be observed also on an international level.

\section{Organisational measures}

Innovative organisational measures like eco-audits will be discussed separately in the following. In terms of their employment effects, the starting point is the hypothesis that their effects are comparable to those of secondary measures. Organisational measures are initially accompanied by additional expenditure and work processes (e.g. undergoing an eco-audit procedure), which create positive direct employment effects, while the indirect effects should depend strongly on whether these organisational measures are internationally coordinated or introduced only on a national basis.

Table 3 gives an overview of our selected case studies according to each type of integrated environmental technologies which have been categorised. In the following these case studies will be analysed in detail. Methodologically, the case studies are based on semi-structured company interviews. Five to six company interviews were conducted per case study following an interview guide with a consistent loose structure:

- general company data;

- description of the integrated technology used and the changes in corporate work processes ensuing from this, compared to a reference state (the reference state ideally being a situation where additive technology is used);

- description of the effects on corporate employment;

- description of possible employment effects outside the company (upstream and downstream areas).

Table 3: $\quad$ Employment-oriented selection of case studies

\begin{tabular}{|l|l|}
\hline Type of integrated measure & Analysed case studies \\
\hline Primary measures & $\begin{array}{l}\text { Processes: Coal power plant } \\
\text { Products: water-solvent car lacquers }\end{array}$ \\
\hline Secondary measures & Waste water-free textile manufacturer \\
\hline Organisational measures & Eco-audits \\
\hline
\end{tabular}


The company interviews have revealed that in small and medium-sized companies (e.g. from the textile industry), the semi-structured interviews could be realised relatively well. In contrast to this, it has proved to be very difficult to assess the employment effects of integrated environmental technologies in large companies (such as car manufacturers, coal power plants), whose work processes are, as a rule, highly complex. As far as it was possible, we used in these cases employment-relevant proxy indicators (turnover, labour costs) for the analyses.

\subsection{Results of the case study coal power plant}

Concerning the operation of modern coal power plants under German economic conditions, i.e. with a very high degree of automation, very few differences in employment effects could be observed for the transition from additive to integrated solutions.

Large power plants can be operated by 3-5 people per shift, which means an average resource demand of 15-30 people. In old coal power plants, about another 130 people are used as technical staff for maintenance and service work, and another 40 as clerical staff. While in former times there was a rule of thumb which stated that for each Megawatt installed power generation one employee was needed, today the hard coal power plant in Rostock, Germany (550 Megawatt) manages with 153 employees. Similarly, the lignite-based power station "Schwarze Pumpe" (2x800 Megawatt) employs only 289 people. This corresponds to an improvement in work productivity by about a factor of 3 to 6 . In the face of these figures, changes in the employment situation brought about by primary protection measures, as far as such changes are identifiable at all, lie in the range of a few percent of the total staff. In a typical 750 Megawatt power plant, which has been upgraded with exhaust flue gas dust collectors (Rauchgasreinigungsanlagen), it can be operated by 2 to 3 additional employees. In the case of new plants the additional components are integrated in a way that no additional personnel is required.

End-of the-pipe flue gas dust collectors (additive technology) contribute $10 \%$ to $15 \%$ to the investment and operating costs of new power plants. This investment leads to indirect employment effects, for example, with suppliers of environmental technology. The extent of this effect is however limited by the existing overcapacity of power plants and the moderate demand resulting from this. A considerable share of the costs for additive measures can be saved by integrated technology, as the burning of exhaust fumes in the process of primary measures (integrated technology) makes the cleaning of these fumes superfluous. Another saving poten- 
tial lies in the fact that cleaning measures can now be concentrated on the fuel gas flows, whose volume sometimes makes up only $5 \%$ of the total exhausts. This statement is supported by the examination results of the upgrading with environmental technology. DM 14-15bn, or DM 200-240 per Kilowatt (KW) generated, were paid after 1983 for the installation of flue gas desulfurisation facilities into existing plants; for DENOX plants, it was another DM 6-7bn. At the time of this observation, additive technology cost DM 120-150/KW, but integrated technologies in lignite-based plants used only DM 70/KW. However, the potential of plants suitable for an upgrading with integrated technologies at acceptable cost was very limited.

Altogether, it can be stated that direct employment effects of primary measures tend to be negative with operators of coal power plants; also they are so moderate that in some cases it is even difficult to identify them at all. For example, the differences in the relationship of upgrading investment and power plant performance between additive and integrated measures may be taken as a rough indicator for potential indirect employment effects with the suppliers of the upgrading technology; if one assumes a shrinking market volume, it may be that up to $50 \%$ of the indirect employment effects caused by primary measures with suppliers of the technology are eliminated. This is contrasted by positive employment effects due to an increase in competitiveness of the energy sector, resulting from falling energy prices.

\subsection{Results of the case study "Low-solvent and solvent-free car paints"}

Low-solvent and solvent-free car paint are an important, growing segment of the international car paint market. Positive direct employment effects by the product innovations are partly offset above all by substitution effects of the replaced environmentally harmful products (which were crowded out). Negative indirect employment effects due to less strong environmental regulations abroad cannot be identified, as the international close inter-linking of car manufacturers and supplier firms have obviously led to a certain amount of uniformity in environmental standards. This may also be linked to the fact that product standards are more easily unified on an international basis than process standards.

It is hardly possible for the individual players in the market to clearly attribute employment figures to product-integrated environmental protection. Manufacturers of painting facilities act in the international market for systems technology with ever changing project consortia, depending on the individual customer demand. As a rule, none of the people involved has an 
overview of the total number of employees involved in the processing of an order. Considering that the employees occupied with the production of a painting street are not registered by the suppliers, the scope of employment effects has to be calculated with the help of proxy variables. Suitable variables include, above all, labour costs in order to obtain at least a rough idea. Altogether, the fluctuation margin for different painting systems remains within in a range of \pm 10 to $20 \%$ of their users. With the more environmentally friendly water-based and powder paints, wage costs are about $10 \%$ lower than with conventional solvent-containing paints. When taking these comparably low differences in cost as a measure, only moderate changes in employment, if any, can be expected.

The example of the paint manufacturer Herberts $\mathrm{GmbH}$ may exemplify how difficult it is to identify the employment effects of the change from manufacturing conventional paints to water-based paints. Herberts, which is based in Wuppertal, focuses on the development of paint systems and respective plasticisers with reduced solvent content. Herberts is the market leader in Europe in the colourful spraying paints business, above all the water-based paints segment, with a market share of 35\%. In Wuppertal, the site where in 19961567 people were employed, the most modern factory for water-based paints in Europe was created.

Of course, the employees cannot simply be regarded as holding jobs additionally created from product-integrated environmental technologies, since a factory for producing conventional paints might have been built alternatively. However, as for the next 10 years of car serial painting, one can expect that solvent-containing paints will be entirely replaced by water-based or powder paints, thus product-integrated environmental technologies makes a valuable contribution to securing jobs.

\subsection{Results of the case study "Waste-water-free textiles refinement business"}

The employment effects resulting from the use of integrated environmental technology concerning the use of waste water in the Textiles Refinement Industry (Textilveredelungsindustrie, German acronym: TVI) can only be assessed in the context of the general economic situation of this industry. The economic situation is characterised by a process which has been in decline for many decades and which is still continuing to weaken. Between 1970 and 1995, the German TVI lost almost $60 \%$ of its employees. High wage costs are regarded as the main reason for this development, although additional obstacles include a lack of working time 
flexibility, high incidental wage costs and constraints caused by huge bureaucracy and high environmental standards. Taking these circumstances into account, it already has to be regarded as a "success" if the transition to adopting integrated environmental technologies makes a contribution to securing the mere existence of the industry.

As a result of the interviews with users of integrated technologies, changes in labour requirements linked to the operation of the facilities turned out to be rather negligible. The transition from an additive to an integrated environmental protection measure represents only a minor influence on the overall employment situation and is, at best, only able to offset some part of the job losses due to rationalisation in other business areas.

Only small employment effects of cleaner production can be be identified for the suppliers of environmental technology or chemicals in the textile refinement industry, too. For example, employment effects in the production of environmentally friendly textile colours at BASF AG, Ludwigshafen, occurred only during the process development. But even here, no significant number of new jobs was registered from the production of environmentally friendlier textile colours. Instead, existing staff was used whose jobs would otherwise have been lost. Also, geographically the suppliers of textile auxiliaries have moved closer to their customers, i.e. the textile industry, which is generally located in newly industrialising and developing countries in South-East-Asia. In 1992, only around $20 \%$ of the worldwide textile colour production came from Europe, whereas newly industrialising and developing countries (including Eastern Europe), which manufactured using lower wages and environmental standards, were already producing more than $50 \%$ market share. In the context of this global development, which is principally dominated by labour costs, the employment effects of the trend towards environmentally friendlier textile colours plays only an insignificant role. A positive employment effect would only be thinkable if internationally binding environmental standards of product-integrated environmental technology were fixed, which would bring advantages for suppliers located near producers of environmentally friendlier textile colours.

Positive experiences of Enviro-Chemie in Roßdorf near Darmstadt, a manufacturer of environmental technology which has specialised in the market niche of process-internal waste water recycling, signal however a certain demand for process-integrated environmental technology. However, it is currently impossible to operate using demanding solutions without substantial subsidies. A general problem for the introduction of process-integrated environmental technology is that a quick amortisation, as with additive facilities, cannot be expected within 2- 
3 years of operation. The main driving force for the demand for integrated technology are high wastewater costs and limited exhaustion rights, which, if the company has to be restructured anyway, ease the decision for integrated solutions.

Altogether, direct and indirect employment effects of secondary measures of integrated environmental protection in the textile refinement industry and in upstream and downstream areas can be identified, but they are only weak. The development of the employment situation is basically determined by other factors of international competition for inward investment (technical rationalisation, wage and incidental wage costs), and direct employment effects of process-integrated measures will only partly be able to offset these factors. On the side of the users, a certain, limited number of positive employment effects arise for the operation of waste water treatment facilities; negative direct employment effects can be created by the investment risk (e.g. if the desired reuse of the waste water does not turn out to be practical). For the suppliers of waste water treatment and recycling facilities, direct employment effects arise above all in the area of process development. The general decline of the TVI is also responsible for declining market volumes. Prospects for successful exporting of textiles that were produced in an environmentally friendlier way are currently still spoilt by the lack of international environmental standards.

\subsection{Results of the case study eco-audits}

Direct employment effects of the implementation and maintenance of eco-audits according to the European Environmental Management Auditing System (EMAS) can be estimated using the cost variables in Table 4. It seems reasonable to differentiate between implementation costs of the installation of an environmental management system and the participation in a specific eco-audit programme. According to the statements made during the company interviews, the participation in an eco-audit costs 3 to 6 internal and 1 to 3 external person months. The internal expenditure for personnel can rise to 1 to 2 person years, if a new environmental management system has to be established from the scratch. The internal and external effort for maintenance ranges between 1.3 and 4.3 person months annually. 
Table 4: Direct employment effects of the installation of an environmental management system and the participation of a company in an EU-Eco-Audit

\begin{tabular}{|l|l|}
\hline \multicolumn{2}{|c|}{ Implementation cost } \\
\hline $\begin{array}{l}\text { Internal personnel expediture for the } \\
\text { establishment of the environmental } \\
\text { management systems }\end{array}$ & $1-2$ person years \\
\hline $\begin{array}{l}\text { Internal personnel effort for the preparation of } \\
\text { and the participation in the EU-Eco-Audit }\end{array}$ & $3-6$ person months \\
\hline External cost consultants & 1 person month \\
\hline \multicolumn{2}{|c|}{ Cost of maintenance/service } \\
\hline Internal personnel cost & 1 - 4 person months annualy \\
\hline External cost of certification & 1 person month every 3 years \\
\hline
\end{tabular}

Thus the direct employment effect for a certification per site according to EMAS means a unique implementation expenditure of about 4 to 7 person months (which can rise to a level between 13 and 25 months if the system has to be implemented from the scratch), and an annual follow-up expenditure of 1.3 to 4.3 person months. This means that for the 1,175 certifications complying with EMAS (as per 15 March, 1998), in the whole of federal Germany a good 390 to 685 people were fully employeed for the duration of one year. However, the establishment expenditure of an environmental management system standing behind this number of certifications meant with a good 1,300 to 2,400 people a far higher effort. At the sites already certified, approximately 130 to 420 jobs were permanently created or secured by EMAS. All people interviewed reported that their companies appointed experienced employees from their existing staff as audit-agents in charge. Additional staff was employed in none of the enterprises.

If from the number of certifications made in the field of quality management - 20,000 to 30,000 certified plants to date -, a long-term potential for EMAS (and/or ISO 14001) shall be derived, audits can in the long run contribute to the creation or securing of about 2,000 to 10,000 jobs.

As the participation in the audit is voluntary and the proceeding is internationally coordinated, potential negative indirect employment effects can be regarded as negligible and not quantifiable. Currently, in Germany more certified sites have been registered than in all other EU member states together (UMWELT 1998). This may be attributed to the fact that the level of environmental standards in German enterprises is already generally higher than in other countries when they enter the audit-procedure, while other countries face a considerable catch-up 
work and thus also a higher expenditure for an EMAS participation. Positive indirect employment effects through improved competitiveness due to reductions in cost and improvements in quality are possible, but they cannot be allotted so far.

\section{$4 \quad$ Industry Survey}

In order to obtain more represenative statements via a detailed analysis, in a telephone survey more than 400 companies were questioned in detail on the topic "employment effects through environmental innvations“. This survey was carried out by the Centre for European Economic Research $(\mathrm{ZEW})$ in cooperation with the market research institute Infratest Burke Industria in November/December 1997. Along with statements on company structure, the purpose and obstacles posed to the introduction of environmental measures, the questions aimed particularly at the employment situation and the skill structure of the companies and on employment effects of additive and integrated environmental innovations.

The target group of the sample were firms have been identified as being environmentally innovative in the 1996 wave of the Mannheim Innovation Panel (MIP). The MIP is a represenatative survey of the German industry. A company is defined as environmentally innovative if between 1993 and 1995 it carried out at least one of eight environmental innovations listed in the MIP questionnaire and attributed very big or big importance to it. In the written sample of the year 1996, more than 900 enterprises have been identified as environmental innovators. In the additional telephone sample, it was possible to question 419 enterprises successfully. With $45 \%$ the response rate was higher than the usual response rates with company interviews and showed existing interest into the topic environmental innovations.

\subsection{Employment effects resulting from environmental innovations between 1994 and 1996}

In the telephone interviews the companies were asked whether in the different areas in which environmental innovations were introduced the number of employees had increased, remained stable or decreased. Table 5 shows for each of the six environmental areas the percentage of the enterprises with an increase in employment, employment stability and employment decrease. 
With $80 \%$ to $90 \%$ of the companies, the innovations carried out effected no changes in the employment in the six areas of environmental protection. For the remaining $20 \%$, an environmental innovation led rather to an increase than a reduction in employment in the respective area. The only exception is soil decontamination. While in this area $3 \%$ of enterprises noted an increase in employment, $6 \%$ of the enterprises registered a release in these areas. With $14 \%$ the companies with environmental innovations in end-of-pipe emissions control formed the largest group which was able to extend employment. The areas in which the second and third highest percentage of enterprises noted an inrcease in employment, count among the integrated measures for environmental protection.

In their direct impact on employment, environmental innovations are employment neutral with the great majority of the innovative enterprises questioned in the sample. With most of the other companies, environmental innovations effecting a change in the employment situation in one environmental area have rather positive than negative employment effects.

Table 5: $\quad$ Employment effects of environmental innovations between 1994 and 1996

\begin{tabular}{llll}
\hline \hline & increase & Stable & decrease \\
\hline Waste recycling & $6.6 \%$ & $91.2 \%$ & $2.2 \%$ \\
Waste disposal & $8.4 \%$ & $86.3 \%$ & $5.3 \%$ \\
Soil decontamination & $3.1 \%$ & $90.6 \%$ & $6.3 \%$ \\
End-of-pipe emissions control & $14.3 \%$ & $84.1 \%$ & $1.6 \%$ \\
Product integrated innovations & $8.4 \%$ & $91.1 \%$ & $0.5 \%$ \\
Process integrated innovations & $9.7 \%$ & $87.4 \%$ & $2.9 \%$ \\
\hline
\end{tabular}

Source: Telephone sample in additional to the MIP 1997.

\subsection{Employment development according to skill categories}

In this section, the effects of environmental innovations on employment figures will be examined more closely, using three skill categories. In doing so, the examination tackles for the first time the issue of a shift in skill requirements caused by technological change in connection with environmental protection.

Table 6 shows the relative importance of environmental innovations in the context of the total employment dynamics. In the table, those companies are shown which, due to their envi- 
ronmental innovations, increased, decreased or did not change employment in their companies.

Table 6: $\quad$ Employment development resulting from environmental innovations between 1994 and 1996

\begin{tabular}{llll}
\hline \hline & increase & no change & decrease \\
\hline college/university graduates & $11.9 \%$ & $86.2 \%$ & $1.9 \%(14.9 \%)$ \\
& $(21.4 \%)$ & $(17.5 \%)$ & \\
skilled employees & $8.9 \%(57.8 \%)$ & $\begin{array}{l}86.5 \% \\
(53.4 \%)\end{array}$ & $4.6 \%(63.2 \%)$ \\
unskilled/trained employees & $4.6 \%(37.2 \%)$ & $\begin{array}{l}89.7 \% \\
(28.2 \%)\end{array}$ & $5.7 \%(22.5 \%)$ \\
\hline
\end{tabular}

Source: Telephone sample in addition to the MIP, 1997; referring to the companies which recorded an increase (no change, decrease) of employment, the rackets give the percentage of employees with the respective skill level in the entirety of corporate employees.

In $11 \%$ of the companies the employment of college and university graduates increased over the past three years due to the introduction of environmental innovations. This shows how moderate the effects of environmental innovations are. This applies for all three levels of skill alike. For those instances where environmental innovations affect employment in a positive way, the analysis reveals that this means rather a rise in the number of jobs for college and university graduates than for skilled labour, and even less for the unskilled workers or those trained on the job. It becomes obvious that environmental innovations lead to an increased demand for qualified personnel.

This demand for better qualified employees for the carrying out of environmental innovations also shows itself in the fact that in firms displaying an increased demand for academics, the average percentage of this skill level is with $21.4 \%$ by more than $6 \%$ higher than in firms stating a reduction in their number of highly qualified employees. The higher the percentage of the highly qualified in a company already is, the more likely it is that in the area of environmental protection, additional college and university graduates will be required. Also for the nearer future, more environmentally innovative enterprises expect a rise in the number of jobs for skilled and highly skilled labour. 


\section{$5 \quad$ Summary and Conclusions}

The aim of this study is to obtain theoretically and empirically founded statements on employment effects which result from environmental innovations and especially from the increasing trend towards integrated technologies.

Theoretically, integrated environmental technology can trigger expansive employment effects in some companies and contractive effects in others. The effects vary typically between suppliers of and demanders for environmental technologies and between individual industries. Also, the short-term and long-term effects can turn out to be as different as the individual and aggregate economic effects and impact on different levels of skill. Furthermore, the employment effects are dependent on the way of functioning, flexibility and competitive intensity of goods and factor markets.

The central factors for determining the amount of labour required by companies are the profit and turnover expectations, the relative factor costs, the technological feasibility to substitute labour, skill and capital, economies of scope in production and technological progress in the form of innovations. As the stimuli for the embarkment on environmental activities do not exclusively result from market signals, the employment effects of environmental measures are determined by the design of the national and international environmental-political setting.

The results of the case studies and broad samples show that the employment effects of environmental technology are in terms of their nature comparable to those of other innovations. Quantitatively they often have less impact due to considerable substitution effects (a less environmentally friendly technology is replaced). Examples for measures with substantial substitution effects are:

- Process-integrated primary measures within coal poewer plants, replacing end-of-the-pipe technologies,

- low-solvent and solvent-free car lacquers replacing solvent-containing lacquers,

- process-integrated primary recycling in textile improvement enterprises, replacing end-ofthe-pipe technologie.

While process-integrated primary measures in the case study examined score worse in terms of their direct employment effects, they have more positive indirect effects. Thus, they have basically a similar effect like other process innovations. 
Peculiarities of integrated process technologies were revealed in the textile industry case study. Innovations are not only market-dependent but also at least partially induced by government regulations. In these cases process innovations can lead to an increased investment and thus to positive direct employment effetcs. However, negative indirect effects can occur, depending on the market situation and the political setting.

The examined organisational (audits) and product-integrated innovations (car lacquers) showed positive direct employment effects, which however in the case of the car lacquers are at least partly compensated by the crowding out of solvent-containing lacqers. Due to a worldwide trend towards a reduction of the solvent content of car lacquers, these compensation effects exist however rather in theory. Particularly for the product-integrated environmental protection, a comment of the study of the Institute for Prospective Technological Studies (IPTS, 1997) fits here: "The argument for cleaner products and services is that the employment prospects are at least as good on an 'environmental path'; and the environmental consequences are infinitely better. Indeed, we may have little choice in the matter. If other countries go down the environmental route, the demands of international competitiveness may force us to do the same. It may be better to prepare now than wait until we are left behind.“

In summarising the case studies, one could state the following:

- Direct and indirect employment effects of integrated environmental technology are difficult to identify and, in the context of larger effects of general, labour-saving technological progress, even more difficult to measure.

- What is special about process-integrated environmental protection technologies compared to process innovations in other areas is that they contribute not only to rationalisation, but also to complying with environmental regulations. This can bring about positive direct employment effects, which, in the case of a nationally restricted environmental policy, can be opposed by negative indirect effects.

- What is special about environmental product innovations in contrast to product innovations in other areas is that like for process innovations, the market success and thus positive employment effects are at least partly dependent on the national and international economic conditions and regulations.

The telephone sample confirmed the all in all rather moderate employment effects of integrated technology, an observation which is also true for environmental technology as a whole. Depending on their type of innovation, $80 \%$ to $90 \%$ of companies stated that in their firms, 
environmental innovations were employment neutral. As far as effects could be identified, integrated environmental technologies were attributed a positive employment effect second most frequently.

Compared to additive technology, integrated environmental technologies led with more firms to positive employment effects. In up to $5 \%$ of enterprises employment figures fall, in up to $10 \%$ of enterprises they rise. However, in terms of their scope, the positive employment effects which were mainly observed for industrial plants are, due to their low quantity, hardly able to make a noticeable contribution towards the reduction of unemployment. It is not the aim of this study to examine whether this statement can be transferred to the service sector; such a hypothesis would have to be analysed in a separate study. The high proportion of services in the production and establishment of integrated environmental technology and a lower degree of crowding out of additive measures (which are less strongly represented in the service sector), speaks rather for a more dynamic employment development in the service sector.

Just like other innovations also environmental innovations in the mid-nineties tend to be qualification-promoting. The more enterprises innovate in the area of environmental technology and introduce, whereever technically possible, rather integrated than additive environmental technology, the more increases the demand for qualified and even highly qualified labour, and the more decreases the demand for lowly qualified labour. In this respect, environmental innovations are no different from other innovations. In simple words, technology policy in general and the promotion of environmental technologies in particular create low quantity, but high quality jobs.

The development towards using less, but better skilled staff while the production output remains the same, which is also caused by environmental technological progress, can be even increased by economic factors. Little flexible wages and a relatively rigid wage structure could exacerbate the process of job reduction, accompanied by a simultaneous shift towards a higher skill level. Just as innovations in general, successful environmental innovations are not sufficient to prevent the releasing effects particularly with less qualified people, even if they can be designed in a way that the positive employment effects outweigh the negative.

Altogether, all results and all methods used show that the promotion of integrated environmental protection does basically not oppose employment policy, and in some parts even synergies can be stated; however, technology policy in general and the promotion of integrated 
environmental protection in particular alone cannot be expected to solve the problem of mass unemployment.

\section{Acknowledgements:}

The paper is based on a study commissioned by the German Ministry of Edudaction and Research (BMBF). The study was run from 1996 to 1998 and has been published under the title „Beschäftigungswirkungen des Übergangs zu integrierter Umwelttechnik“ (,Employment Impacts of the Transition to Integrated Environmental Technologies") in the Physica-Verlag, Heidelberg. We would like to thank numerous colleagues for their support, but we are especially grateful to Doris Blechinger, Dr. Helmuth-Michael Groscurth, Dr. Georg Licht and Stefan Vögele for their contributions to the case studies and surveys.

\section{References:}

Bartel, A.P., F.R. Lichtenberg (1987) „The Comparative Advantage of Educated Workers in Implementing New Technology“, in: The Review of Economics and Statistics No. 1, Vol. LXIX, pp. 1-11.

Blazejczak, J., D. Edler, M. Gornig (1993) Beschäftigungswirkungen des Umweltschutzes Stand und Perspektiven. Forschungsvorhaben im UFOPLAN, Berlin. Schmidt-Verlag.

Blazejczak, J., D. Edler, M. Gornig (1994) „Grüne Arbeitsplätze: Umweltpolitik und Strukturwandel der Beschäftigung“, in: Aus Politik und Zeitgeschichte, 44. Jahrgang.

Blechinger, D., A. Kleinknecht, G. Licht, F. Pfeiffer (1998): The Impacts of Innovation on Employment in Europe - An Analysis using CIS Data. ZEW-Dokumentation Nr. 98-02, Mannheim.

Blechinger, D., F. Pfeiffer (1997) „Humankapital und technischer Fortschritt“, in: G. Clar, J. Dore und H. Mohr (Eds.): Humankapital und Wissen - Grundlagen einer nachhaltigen Entwicklung, Springer-Verlag. Berlin, Heidelberg.

BMBF - Bundesministerium für Bildung und Forschung (1994) Produktionsintegrierter Umweltschutz - Vermeidung von Umweltbelastungen aus der industriellen Produktion, Förderkonzept des Bundesministeriums für Forschung und Technologie. Bonn.

Bovenberg, A.L., F. van der Ploeg (1994) „Consequences of environmetal tax reform for involuntary unemployment and welfare“, Center for Economic Research, No. 9408. 
Coenen, R. S. Klein-Vielhauer, R. Meyer (1995) Integrierte Umwelttechnik - Chancen erkennen und nutzen, Endbericht des TA-Projektes „Umwelttechnik und wirtschaftliche Entwicklung“. Arbeitsbericht Nr. 35 des Büros für Technikfolgen-Abschätzung beim Deutschen Bundestag, Bonn.

DIW, Ifo, IWH, RWI (1996) Umweltpolitik: Aktualisierte Berechnung der umweltschutzinduzierten Beschäftigung in Deutschland, Eine Information des Bundesumweltministeriums, Bonn.

Goodstein, E. (1995) „Jobs or the Environment? No trade-off“, in: Challenge, Januar-Februar, pp. 41-45.

Hamermesh, M. (1993) „Labour Demand“, Princeton.

Hansen, J. (1996) „Produktions- und produktintegrierter Umweltschutz“, in: Industrie Management, 12. Jg., Nr. 2, pp. 63-67.

Hemmelskamp, J. (1997) Umweltpolitik und Innovation - Grundlegende Begriffe und Zusammenhänge. In: Zeitschrift für Umweltpolitk \& Umweltrecht, 4/97, pp. 481 -511.

Hohmeyer, O., H. Koschel (1995) Umweltpoltische Instrumente zur Förderung des Einsatzes integrierter Umwelttechnik, Gutachten im Auftrag des Büros für TechnikfolgenAbschätzung beim Deutschen Bundestag (TAB), ZEW, Mannheim.

IPTS - Institute for Prospective Technological Studies (1997): Environment and Employment - A report by the IPTS for the Committee on Environment, Public Health and Consumer Protection of the European Parliament, Sevilla.

Katsaloucas, Y. (1986) The Employment Effect of Technical Change. A Theoretical Study of New Technology and the Labour Market, Oxford.

König, H. (1997): „Innovation und Beschäftigung“, in: H. J. Vosgerau und H. König (Eds.): Zentrum und Peripherie - Zur Entwicklung der Arbeitsteilung in Europa, Schriften des Vereins für Socialpolitik, Volume 250.

Porter, M.E., C. van der Linde (1995): „Green and Competitive: Ending the Stalemate“, in: Harvard Business Review, September - October 1995, pp. 120-134.

Schneider, K. (1996) „Involuntary Unemployment and Environmental Policy: The Double dividend Hypothesis“, unpublished manuscript, University Dortmund.

Stoneman, P. (1983) The Economic Analysis of Technological Change, Oxford.

Tirole, J. (1989) The Theory of Industrial Organization, Cambridge. 
Umwelt (1998) „Registrierung des 1.000 Unternehmensstandortes im Rahmen des UmweltAudits“, in: Umwelt, 3/1998, p. 98. 